Research paper

\title{
Synthesis, antiarrhythmic activity, and toxicological evaluation of mexiletine analogues
}

\author{
Mariagrazia Roselli a , Alessia Carocci ${ }^{\text {a, }}$, Roberta Budriesi ${ }^{\text {b }}$, Matteo Micucci ${ }^{\text {b }}$, \\ Maddalena Toma a, Lorenzo Di Cesare Mannelli ${ }^{\mathrm{c}}$, Angelo Lovece ${ }^{\mathrm{a}}$, Alessia Catalano ${ }^{\mathrm{a}}$, \\ Maria Maddalena Cavalluzzi a , Claudio Bruno a, Annalisa De Palma ${ }^{\mathrm{d}}$, \\ Marialessandra Contino a , Maria Grazia Perrone a, Nicola Antonio Colabufo a , \\ Alberto Chiarini ${ }^{\mathrm{b}}$, Carlo Franchini ${ }^{\mathrm{a}}$, Carla Ghelardini ${ }^{\mathrm{c}}$, Solomon Habtemariam ${ }^{\mathrm{e}}$, \\ Giovanni Lentini ${ }^{\text {a }}$ \\ a Dipartimento di Farmacia-Scienze del Farmaco, Università degli Studi di Bari Aldo Moro, Via E. Orabona n. 4, 70126 Bari, Italy \\ ${ }^{\mathrm{b}}$ Dipartimento di Farmacia e Biotecnologie, Università di Bologna, Via Belmeloro 6, 40126 Bologna, Italy \\ ${ }^{c}$ Dipartimento di Farmacologia Preclinica e Clinica, Università di Firenze, Viale Pieraccini 6, 50139 Firenze, Italy \\ ${ }^{\mathrm{d}}$ Dipartimento di Bioscienze, Biotecnologie e Biofarmaceutica, Università degli Studi di Bari Aldo Moro, Via Orabona 4, 70126 Bari, Italy \\ e Pharmacognosy Research Laboratories \& Herbal Analysis Services, Chatham-Maritime, Kent ME4 4TB, UK
}

\section{A R T I C L E I N F O}

\section{Article history:}

Received 14 March 2016

Received in revised form

20 May 2016

Accepted 21 May 2016

Available online 24 May 2016

\section{Keywords:}

Mexiletine

Antiarrhythmics

P-glycoprotein

Inotropism

MW-assisted synthesis

\begin{abstract}
A B S T R A C T
Four mexiletine analogues have been tested for their antiarrhythmic, inotropic, and chronotropic effects on isolated guinea pig heart tissues and to assess calcium antagonist activity, in comparison with the parent compound mexiletine. All analogues showed from moderate to high antiarrhythmic activity. In particular, three of them (1b,c,e) were more active and potent than the reference drug, while exhibiting only modest or no negative inotropic and chronotropic effects and vasorelaxant activity, thus showing high selectivity of action. All compounds showed no cytotoxicity and $\mathbf{1 b}, \mathbf{c}, \mathbf{d}$ did not impair motor coordination. All in, these new analogues exhibit an interesting cardiovascular profile and deserve further investigation.
\end{abstract}

(c) 2016 Elsevier Masson SAS. All rights reserved.

\section{Introduction}

One of the major causes of mortality is represented by cardiovascular diseases and about $25 \%$ of cardiovascular-related adverse events are caused by arrhythmias. The term arrhythmia defines an abnormality in the sequence and/or shape of electrical impulses during the cardiac cycle. A critical role in the regulation of electrical activity of cardiac cells is played by ion channels such as sodium,

Abbreviations used: CNS, central nervous system; DMEM, Dulbecco's modified eagle's medium; GPILSM, guinea pig ileum longitudinal smooth muscle; HepG2, human hepatocellular liver carcinoma cells; MDCK, Madin-Darby canine kidney; MDCK-MDR1, MDCK overexpressing P-gp; MTT, 3-(4,5-dimethylthiazol-2-yl)-2,5diphenyltetrazolium bromide; MW, microwave; P-gp, P-glycoprotein; PSS, physiological salt solution.

* Corresponding author.

E-mail address: alessia.carocci@uniba.it (A. Carocci). calcium and potassium channels. Abnormalities in the expression and/or function of ion channels are responsible of many arrhythmias [1,2], thus, they represent one of the targets for antiarrhythmic therapy. Indeed, most of the existing antiarrhythmic agents, such as lidocaine, tocainide, and mexiletine [3,4] are ion channel blockers. Mexiletine (1a, Fig. 1) is an antiarrhythmic drug belonging to class IB. It is a voltage-gated sodium channel blocker whose mechanism of action is related to its preferential binding to the open and/or inactivated states of the channels. The selective action of mexiletine on pathologically hyperactive tissues seems to be related to the use-dependent blockade of sodium channels [5]. Mexiletine undergoes extensive metabolism; eleven phase I metabolites of mexiletine have been identified [6,7]. Mexiletine is predominantly used in the treatment of ventricular arrhythmias, however, recent studies have demonstrated its therapeutic value for treating many other disorders associated with voltage-gated sodium channel 


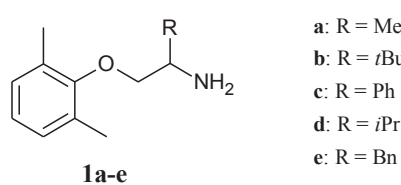

Fig. 1. Structures of mexiletine (1a) and its analogues (1)-e).

dysfunction including chronic painful diabetic neuropathy [8], neuropathic pain [9], myotonic syndromes [10], and Timothy syndrome [11]. Recently, mexiletine has been successfully used in the treatment of sporadic amyotrophic lateral sclerosis [12-14]. Despite all these reported therapeutic values, the use of mexiletine is characterized by several drawbacks including epigastric discomfort, atrioventricular heart block, and CNS disturbances [15]. Hence, it has now been discontinued in many countries including the US and the UK [16]. Consequently, numerous attempts have been made in recent years to develop an alternative to mexiletine, including the design of new analogues that offer the same pharmacological effect but without the unwanted side effects. In the past decade, our own laboratories have been focusing on the development of such analogues through which the structural determinants for blocking voltage-gated sodium channels of skeletal muscles have been established [17-20]. As these identified compounds were more potent channel blockers than the parent compound, they have been proposed as mexiletine alternatives for the treatment of myotonias. We also established that the activity of mexiletine-like sodium channel blockers is strongly linked to the part of the molecule nearby the asymmetric carbon atom. In order to evaluate the potential of these compounds for treating arrhythmias, we selected the most interesting compounds from the previously reported series (1c-e, Fig. 1) that bear a bulky group at the stereogenic center. These compounds, along with a new additional compound, $\mathbf{1 b}$, bearing a tert-butyl group as substituent were prepared by alternative and efficient synthetic routes. The biological activity of all compounds was assessed with due comparison with mexiletine.

\section{Results and discussion}

\subsection{Chemistry}

Mexiletine (1a) and its analogues (1),c) were prepared in two steps according to the synthetic route depicted in Scheme 1, carried out in both traditional conditions and microwave-assisted synthesis. In the first step, 2,6-dimethylphenol underwent Williamson reaction [21] with the suitable halo ketone $(\mathbf{2 a}-\mathbf{c})$ to obtain aryloxyalkyl ketones $(\mathbf{3 a}-\mathbf{c})$ which were converted into the corresponding amines $\mathbf{1 a}-\mathbf{c}$ by reductive amination under both traditional and microwave conditions [22]. The corresponding hydrochloride salts $(\mathbf{1} \mathbf{a}-\mathbf{c} \cdot \mathbf{H C l})$ were obtained by treating $\mathbf{1 a}-\mathbf{c}$ with gaseous $\mathrm{HCl}$. Mexiletine analogues 1d,e were prepared as depicted in Scheme 2. Compounds 5d,e were obtained by protecting the corresponding commercial valinol and phenylalaninol, respectively, with di-tert-butyl dicarbonate $[23,24]$. Compounds 5d,e were subjected to Mitsunobu reaction with 2,6dimethylphenol as previously described [25]. The so obtained aryl alkyl ethers $\mathbf{6 d , e}$ were treated with gaseous $\mathrm{HCl}$ to give the corresponding amines as hydrochloride salts (1d,e·HCl).

\subsection{Biological results}

Mexiletine and its analogues $(\mathbf{1} \mathbf{a}-\mathbf{e})$ were tested in vitro for their antiarrhythmic activity on guinea pig isolated left atria driven at $1 \mathrm{~Hz}$. Compound $\mathbf{1 b}, \mathbf{c}, \mathbf{e}$ increased the threshold of ac-arrhythmia more than mexiletine did, while 1d showed an anti-arrhythmic activity comparable to that of the parent compound, mexiletine (Table 1). In particular, compound 1c was found to be 27 -fold more active than mexiletine. To better define the cardiac profile of mexiletine analogues, their influence on additional cardiac parameters were compared with that elicited by the reference compound, mexiletine (Table 2). All the tested compounds strongly decreased the developed tension on driven left atria with $\mathrm{EC}_{50}$ values within the range of 0.012 and $0.042 \mathrm{mM}$. The most potent analogue was 1e showing a negative inotropism 4-fold higher than that of mexiletine (Table 2), while its antiarrhythmic potency was 2.7-fold higher than that of mexiletine (Table 1). The effect of $\mathbf{1 b}$ was comparable to that of mexiletine. It is noteworthy that the introduction of an aromatic moiety, in lieu of the methyl one, on the stereogenic center as in 1c and 1e, strongly increased antiarrhythmic and negative inotropic potency. On the other hand, the introduction of an isopropyl group, as in 1d, while slightly affecting the antiarrhythmic activity, enhanced two times the negative inotropic effect. With regard to the negative chronotropic activity on spontaneously beating right atrium, only compound 1d showed a weak activity, about 900 -fold lower than that of mexiletine. Furthermore, 1b,c,e showed negative inotropism on spontaneously beating isolated right atrium, too. It is noteworthy that this effect was not recorded for mexiletine and 1d due to their insignificant inotropism resulting from chronotropic effect. Moreover, all the new mexiletine analogues were tested on $\mathrm{K}^{+}$-depolarized $(80 \mathrm{mM}$ $\mathrm{KCl})$ guinea pig aortic strips to assess their vasorelaxant activity. Data are shown in Table 3 with mexiletine as the reference drug. For all compounds, the intrinsic vasorelaxant activity percentage on aorta was lower than $40 \%$ and thus unremarkable. In order to rule out a possible inhibitory effect on nonvascular smooth muscle, such as that displayed by $\mathrm{Ca}^{2+}$ channel antagonists, further investigation on relaxant activity using $\mathrm{K}^{+}$-depolarized $(80 \mathrm{mM} \mathrm{KCl})$ guinea pig ileum longitudinal smooth muscle (GPILSM) was pursued (Table 3 ). The observed profile of intrinsic activity and potency for $\mathbf{1 b}, \mathbf{c}, \mathbf{d}$ was, however, substantially similar to that displayed by mexiletine. Only compound 1e showed a relaxant potency slightly higher than that of the parent compound, but in the micromolar range. Over all, all the compounds appears to display a higher intrinsic activity in nonvascular than vascular smooth muscle cells. Since mexiletine clinical use is often associated to CNS toxicity, a preliminary toxicological evaluation of mexiletine analogues was performed by assessing the motor coordination of treated animals using the rotarod test (Table 4). All compounds at the dose of $25 \mathrm{mg} / \mathrm{kg}$ ip did not

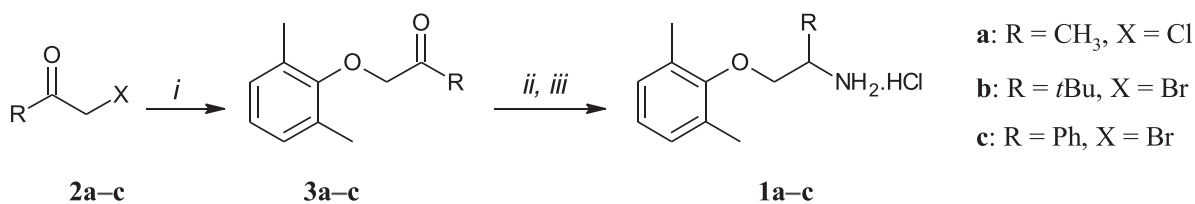

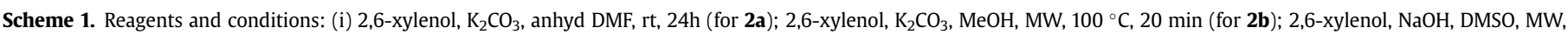
$60{ }^{\circ} \mathrm{C}, 15 \mathrm{~min}$ (for 2c); (ii) $\mathrm{NaBH}_{3} \mathrm{CN}, \mathrm{AcONH}_{4}, \mathrm{MeOH}$, rt (or MW, $110{ }^{\circ} \mathrm{C}, 11 \mathrm{~min}$ ); (iii) anhyd $\mathrm{Et}_{2} \mathrm{O}$, gaseous $\mathrm{HCl}$. 


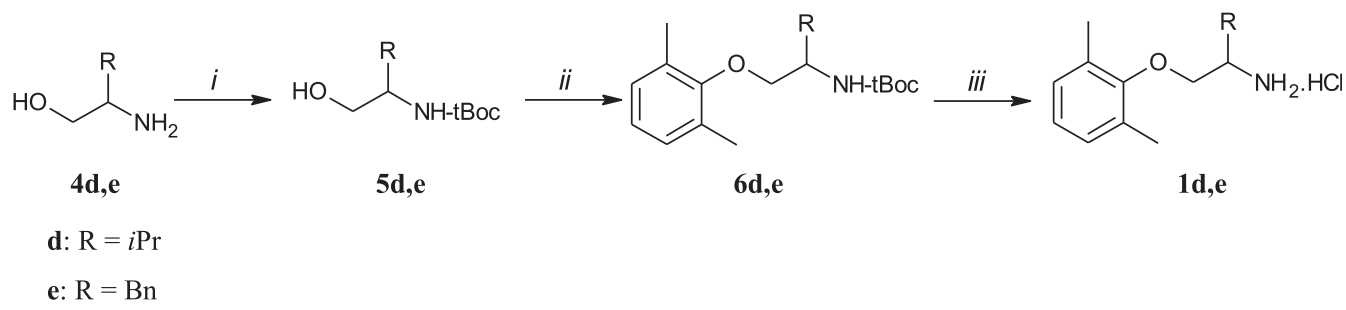

Scheme 2. Reagents and conditions: (i) $\mathrm{Boc}_{2} \mathrm{O}, 1 \mathrm{M} \mathrm{NaOH}, \mathrm{THF}, \mathrm{rt}$; (ii) 2,6-xylenol, DIAD, $\mathrm{PPh}_{3}$, anhyd THF, rt; (iii) anhyd Et $2 \mathrm{O}$, gaseous $\mathrm{HCl}$.

Table 1

Antiarrhythmic activity of compounds $\mathbf{1 a}-\mathbf{e}$.

\begin{tabular}{llcc}
\hline Compd & ${\text { Max } \% \text { increase }^{\mathrm{a}}(\text { mean } \pm \mathrm{SEM})}$ & $\mathrm{EC}_{50}{ }^{\mathrm{b}}(\mu \mathrm{M})$ & $95 \%$ confidence limit $\left.\times 10^{-6}\right)$ \\
\hline $\mathbf{1 a}$ & $64 \pm 1.4$ & 11.6 & $8.71-13.5$ \\
$\mathbf{1 b}$ & $71 \pm 2.4^{\mathrm{c}}$ & 2.11 & $1.38-3.20$ \\
$\mathbf{1 c}$ & $135 \pm 2.2^{\mathrm{d}}$ & 0.43 & $0.34-0.54$ \\
$\mathbf{1 d}$ & $145 \pm 4$ & 18.4 & $14.9-22.7$ \\
1e & $169 \pm 4^{\mathrm{c}}$ & 4.36 & $1.47-6.38$ \\
\hline
\end{tabular}

${ }^{a}$ Increase of threshold of ac-arrhythmia: increase in the intensity of $50 \mathrm{~Hz}$ alternating current required to produce arrhythmia in guinea pig left atria driven at $1 \mathrm{~Hz}$ in the presence of each tested compounds at $10^{-4} \mathrm{M}$. For all data $P<0.05$.

b Calculated from log concentration-response curves (Probit analysis according to Litchfield and Wilcoxon [35] with $n=6-8$ ). When the maximum effect was $<50 \%$, the $\mathrm{EC}_{50}$ values were not calculated.

${ }^{c}$ At $10^{-5} \mathrm{M}$.

${ }^{\mathrm{d}}$ At $5 \times 10^{-6} \mathrm{M}$.

\section{Table 2}

Influences of tested compounds on cardiovascular parameters.

\begin{tabular}{|c|c|c|c|c|c|c|c|c|c|}
\hline \multirow[t]{3}{*}{ Compd } & \multicolumn{3}{|l|}{ Left atrium } & \multicolumn{6}{|c|}{ Right atrium } \\
\hline & \multicolumn{3}{|c|}{ Negative inotropy } & \multicolumn{3}{|c|}{ Negative inotropy } & \multicolumn{3}{|c|}{ Negative chronotropy } \\
\hline & $\begin{array}{l}\text { Activity }^{\mathrm{a}} \\
(\% \pm \text { SEM })\end{array}$ & $\begin{array}{l}\mathrm{EC}_{50} \mathrm{~b}^{\mathrm{b}} \\
(\mu \mathrm{M})\end{array}$ & $\begin{array}{l}\text { 95\% confidence lim } \\
\left(\times 10^{-6}\right)\end{array}$ & $\begin{array}{l}\text { Activity } \\
(\% \pm \text { SEM })\end{array}$ & $\begin{array}{l}\mathrm{EC}_{50} \mathrm{~b}^{\mathrm{b}} \\
(\mu \mathrm{M})\end{array}$ & $\begin{array}{l}\text { 95\% confidence lim } \\
\left(\times 10^{-6}\right)\end{array}$ & $\begin{array}{l}\text { Activity }^{\mathrm{d}} \\
(\% \pm \text { SEM })\end{array}$ & $\begin{array}{l}\mathrm{EC}_{50} \mathrm{~b} \\
(\mu \mathrm{M})\end{array}$ & $\begin{array}{l}95 \% \text { confidence lim } \\
\left(\times 10^{-6}\right)\end{array}$ \\
\hline $1 \mathbf{a}$ & $90 \pm 1^{*}$ & 0.045 & $0.035-0.058$ & & & & $85 \pm 3^{*} g$ & 0.014 & $0.009-0.023$ \\
\hline 1b & $92 \pm 1^{*}$ & 0.042 & $0.027-0.060$ & $77 \pm 1$ & 1.02 & $0.85-3.05$ & $7.0 \pm 0.3^{i}$ & & \\
\hline 1c & $94 \pm 2^{* \mathrm{e}}$ & 0.029 & $0.017-0.052$ & $54 \pm 2^{\mathrm{h}}$ & 8.2 & $4.6-10.4$ & $11 \pm 1^{i}$ & & \\
\hline 1d & $84 \pm 2^{* \mathrm{f}}$ & 0.021 & $0.012-0.037$ & & & & $55 \pm 2^{* f}$ & 13.1 & $10.1-15.0$ \\
\hline $1 e$ & $79 \pm 2^{* g}$ & 0.012 & $0.010-0.015$ & $57 \pm 3$ & 0.066 & $0.048-0.091$ & $24 \pm 2^{*}$ & & \\
\hline
\end{tabular}

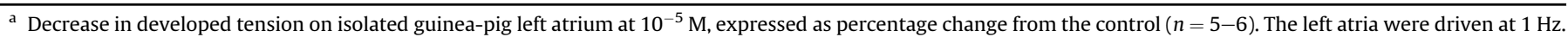
The $10^{-5} \mathrm{M}$ concentration gave the maximum effect for most compounds.

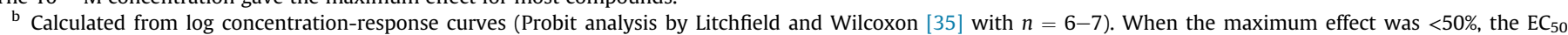
inotropic, $\mathrm{EC}_{50}$ chronotropic and $\mathrm{IC}_{50}$ vasorelaxant values were not calculated.

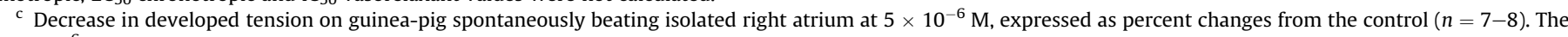
$5 \times 10^{-6} \mathrm{M}$ concentration gave the maximum effect for most compounds.

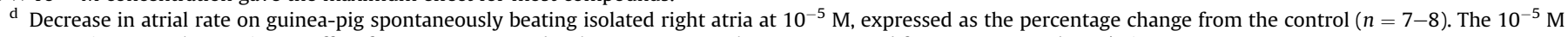
concentration gave the maximum effect for most compounds. The pretreatment heart rate ranged from 170 to 195 beats/min.

e At $5 \times 10^{-6} \mathrm{M}$.

f At $10^{-4} \mathrm{M}$.

g At $10^{-7} \mathrm{M}$.

h At $10^{-5} \mathrm{M}$.

i $P>0.05$. An asterisk indicates $P<0.05$.

Table 3

Relaxant activity of compounds on $\mathrm{K}^{+}$-depolarized guinea pig vascular and non-vascular smooth muscle.

\begin{tabular}{|c|c|c|c|c|}
\hline \multirow[t]{2}{*}{ Compd } & \multirow{2}{*}{$\begin{array}{l}\text { Aorta } \\
\text { Activity }^{\mathrm{a}}(\% \pm \text { S.E.M. })\end{array}$} & \multicolumn{3}{|l|}{ Ileum } \\
\hline & & Activity $^{\mathrm{a}}(\% \pm$ S.E.M.) & $\mathrm{IC}_{50}^{\mathrm{b}}(\mu \mathrm{M})$ & $95 \%$ confidence $\lim \left(\times 10^{-6}\right)$ \\
\hline 1a & $5.0 \pm 0.3$ & $81 \pm 2$ & 8.5 & $6.5-11.1$ \\
\hline 1b & $38 \pm 2$ & $73 \pm 2^{c}$ & 10.7 & $9.0-12.8$ \\
\hline 1c & $31 \pm 2$ & $75 \pm 3^{d}$ & 13.8 & $10.8-17.5$ \\
\hline 1d & $11 \pm 1$ & $88 \pm 1$ & 19.6 & $12.0-25.0$ \\
\hline 1e & $33 \pm 1$ & $73 \pm 2^{d}$ & 3.6 & $2.8-4.6$ \\
\hline
\end{tabular}

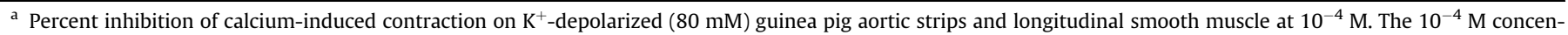
tration gave the maximum effect for most compounds.

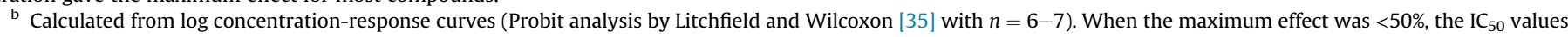
were not calculated.

c At $5 \times 10^{-5} \mathrm{M}$.

d At $10^{-5} \mathrm{M}$. 
Table 4

Effect of mexiletine and its analogues on motor coordination expressed as number of falls from Rota-rod. ${ }^{a}$

\begin{tabular}{|c|c|c|c|c|c|}
\hline \multirow[t]{3}{*}{ Treatment } & \multirow[t]{3}{*}{ Dose, $\mathrm{mg} \mathrm{kg}^{-1}$ ip } & \multicolumn{4}{|c|}{ Falls from the rota-rod } \\
\hline & & \multirow[t]{2}{*}{ Before treatment } & \multicolumn{3}{|c|}{ After treatment } \\
\hline & & & $30 \mathrm{~min}$ & $45 \mathrm{~min}$ & $60 \mathrm{~min}$ \\
\hline Saline & & $4.4 \pm 1.1$ & $2.5 \pm 0.7$ & $1.2 \pm 0.5$ & $0.9 \pm 0.3$ \\
\hline $1 \mathbf{a}^{\mathrm{b}}$ & 25 & $2.8 \pm 0.5$ & $1.3 \pm 0.4$ & $0.8 \pm 0.3$ & - \\
\hline $1 a^{b}$ & 50 & $2.4 \pm 0.3$ & $3.8 \pm 0.3$ & $3.5 \pm 0.2$ & - \\
\hline 1b & 25 & $4.6 \pm 0.5$ & $2.7 \pm 0.4$ & $1.7 \pm 0.4$ & $0.8 \pm 0.2$ \\
\hline 1b & 50 & $4.7 \pm 0.4$ & $3.1 \pm 0.3$ & $1.8 \pm 0.5$ & $1.2 \pm 0.6$ \\
\hline 1c & 25 & $4.3 \pm 0.5$ & $2.4 \pm 0.3$ & $1.8 \pm 0.4$ & $1.3 \pm 0.3$ \\
\hline 1c & 50 & $4.5 \pm 0.6$ & $3.2 \pm 1.6$ & $2.8 \pm 0.7$ & $1.0 \pm 0.2$ \\
\hline 1d & 25 & $4.8 \pm 0.7$ & $2.6 \pm 0.8$ & $2.2 \pm 0.6$ & $1.1 \pm 0.3$ \\
\hline 1d & 50 & $4.5 \pm 0.6$ & $3.0 \pm 1.4$ & $2.1 \pm 1.3$ & $1.0 \pm 1.2$ \\
\hline 1e & 25 & $4.5 \pm 0.9$ & $2.9 \pm 0.8$ & $1.9 \pm 0.5$ & $1.2 \pm 0.5$ \\
\hline 1e & 50 & $4.2 \pm 0.8$ & $4.4 \pm 1.1^{*}$ & $3.5 \pm 0.9^{*}$ & $1.3 \pm 1.1$ \\
\hline
\end{tabular}

${ }^{*} \mathrm{P}<0.05$ in comparison with saline-treated mice.

a Each value represents the mean of 8 mice.

${ }^{b}$ Ref. [16].

provoke any change in normal behavior of mice as demonstrated in rota-rod experiments. At the dose of $50 \mathrm{mg} / \mathrm{kg}$ ip, only compound 1e showed a significant impairment of mouse motor coordination, with a slight increase in the number of falls being displayed. Since mexiletine is known to undergo extensive first-pass oxidative metabolism $[16,26,27]$ that is linked to the generation of reactive species metabolites and/or cellular oxidative stress, the cytotoxicity of the four analogues was assessed using the MTT cell viability assay [28]. When the human hepatocellular liver carcinoma cells (HepG2) were challenged with the four mexiletine analogues at two concentrations (the first close to their corresponding $\mathrm{EC}_{50}$ values, and the second 10-fold higher than the former), no cytotoxicity was observed (data not shown). This finding was in agreement with the previous report for mexiletine where cell viability was not affected at similar concentration range [16]. In addition, we tried to verify if these analogues may display differential ability to interact with Pglycoprotein (P-gp), an ATPase protein highly expressed in biological membranes, that generally affects pharmacokinetics, efficacy, safety, and tissue levels of drugs. For this, drug-protein interaction was assessed for each compound by using the Madin-Darby canine kidney (MDCK) cells overexpressing the ATPase protein P-gp (MDCK-MDR1). As shown in Table 5, only compounds that bear a phenyl ring near the basic center (1c,e) was able to bind P-gp. This data was in good agreement with a recent study on a series of structurally related rigid analogues [29].

\section{Conclusions}

Four mexiletine analogues differing for the substituent on the stereogenic center have been tested for their antiarrhythmic, inotropic, and chronotropic effects on isolated guinea pig heart tissues and for their calcium antagonist activity on GPILSM, in

Table 5

P-gp interaction of mexiletine (1a) and its analogues (1b-e)

\begin{tabular}{ll}
\hline Compd & $\mathrm{EC}_{50} \pm \mathrm{SEM},{ }^{\mathrm{a}} \mu \mathrm{M}$ P-gp \\
\hline 1a & $\mathrm{NA}^{\mathrm{b}, \mathrm{c}}$ \\
1b & $\mathrm{NA}^{\mathrm{b}}$ \\
1c & $27 \pm 5$ \\
1d & $\mathrm{NA}^{\mathrm{b}}$ \\
1e & $8.4 \pm 1.5$ \\
\hline
\end{tabular}

a The value is the mean of three different experiments samples in duplicate.

b $\mathrm{NA}=$ No activity at $100 \mu \mathrm{M}$.

c Ref. [31]. comparison with mexiletine. Even if with different degrees of potency, antiarrhythmic activity has been observed in all the studied compounds, conceivably suggesting the hypothesis that the substitution of the methyl group of mexiletine with a bulky one, strengthens the interaction with the biological structures involved in the regulation of heart activity. In particular, compounds $\mathbf{1 b}, \mathbf{c}, \mathbf{e}$ showed high antiarrhythmic activity, exhibiting $\mathrm{EC}_{50}$ values in the range between 0.43 and $4.36 \mu \mathrm{M}$, thus comparing favorably with the reference drug mexiletine $\left(\mathrm{EC}_{50}=11.6 \mu \mathrm{M}\right)$. These compounds exhibit an interesting cardiovascular profile, being endowed with high antiarrhythmic activity and potency with only modest or no negative inotropic and chronotropic effects and vasorelaxant activity. When administered intraperitoneally $\left(25 \mathrm{mg} \mathrm{kg}^{-1}\right)$, all compounds did not impair motor coordination as demonstrated in rota-rod experiments and showed no in vitro cytotoxicity at concentration 10 times higher than the corresponding antiarrhythmic $\mathrm{EC}_{50}$ values. On the basis that the observed favorable profile should not be affected by interaction with P-gp, compounds $\mathbf{1 b}$ and 1d could be considered as the preferred choices. Taken all the data together, this work afforded compounds endowed with better antiarrhythmic activity along with similar or less cardiovascular effects than mexiletine, thus presenting a higher selectivity of action and reduced side effects. In this respect, the $t$-butyl substituted mexiletine analogue $\mathbf{1 b}$ seems to be the most interesting compound. Further investigation would allow more complete knowledge about its pharmacological potential and mechanism of action, which in turn might allow the design and development of even more active and potent antiarrhythmic agents.

\section{Experimental protocols}

\subsection{Chemistry}

Chemicals were purchased from Sigma-Aldrich or Lancaster. Yields refer to purified products and were not optimized. The structures of the compounds were confirmed by routine spectrometric and spectroscopic analyses. Only spectra for compounds not previously described are given. The reaction under microwaves irradiation were carried out at constant temperature in a CEM Discover BenchMate microwave reactor, with continuous stirring. The temperature was measured and controlled by a built-in infrared detector. Melting points were determined on a Gallenkamp apparatus in open glass capillary tubes and are uncorrected. Infrared spectra were recorded on a Perkin-Elmer (Norwalk, CT) Spectrum One FT spectrophotometer and band positions are given 
in reciprocal centimeters $\left(\mathrm{cm}^{-1}\right) .{ }^{1} \mathrm{H}$ NMR and ${ }^{13} \mathrm{C}$ NMR spectra were recorded on either a Varian VX Mercury spectrometer operating at 300 and $75 \mathrm{MHz}$ for ${ }^{1} \mathrm{H}$ and ${ }^{13} \mathrm{C}$, respectively, or an AGILENT $500 \mathrm{MHz}$ operating at 500 and $125 \mathrm{MHz}$ for ${ }^{1} \mathrm{H}$ and ${ }^{13} \mathrm{C}$, respectively, using $\mathrm{CDCl}_{3}$ and $\mathrm{CD}_{3} \mathrm{OD}$ as solvents. Chemical shifts $(\delta)$ are reported in ppm relative to the residual non-deuterated solvent resonance: $\mathrm{CDCl}_{3}, \delta=7.26\left({ }^{1} \mathrm{H}\right.$ NMR $)$ and $\delta=77.3\left({ }^{13} \mathrm{C} \mathrm{NMR}\right) ; \mathrm{CD}_{3} \mathrm{OD}, \delta=3.30$ $\left({ }^{1} \mathrm{H}\right.$ NMR) and $\delta=47.8\left({ }^{13} \mathrm{C}\right.$ NMR $)$ as internal references. Coupling constants $(J)$ are given in $\mathrm{Hz}$. Gas chromatography (GC)/mass spectroscopy (MS) was performed on a Hewlett-Packard 6890-5973 MSD at low resolution. Liquid chromatography (LC)/ mass spectroscopy (MS) was performed on a spectrometer Agilent 1100 series LC-MSD Trap System VL. Elemental analyses were performed on a Eurovector Euro EA 3000 analyzer and the data for $\mathrm{C}, \mathrm{H}, \mathrm{N}$ were within \pm 0.4 of theoretical values. Chromatographic separations were performed on silica gel columns by column chromatography on silica gel (Kieselgel 60, 0.040-0.063 mm, Merck, Darmstadt, Germany) as described by Still et al. [30]. TLC analyses were performed on precoated silica gel on aluminum sheets (Kieselgel $60 \mathrm{~F}_{254}$, Merck).

\subsubsection{1-(2,6-Dimethylphenoxy)propan-2-amine (1a)}

The preparation of $\mathbf{1 a}$ was performed under both traditional (method A) and microwaves conditions (method B) [31].

4.1.1.1. Method A. Ammonium acetate $(23.8 \mathrm{~g}, 310 \mathrm{mmol})$ and sodium cyanoborohydride $(1.4 \mathrm{~g}, 21.7 \mathrm{mmol})$ were added to a solution of 1-(2,6-dimethylphenoxy)propan-2-one (3a) (5.5 g, $31 \mathrm{mmol}$ ) in $40 \mathrm{~mL}$ of $\mathrm{MeOH}$. The reaction mixture was stirred for four days at room temperature. $6 \mathrm{M} \mathrm{HCl}$ was added dropwise to the mixture reaction to destroy the excess hydride. The organic solvent was removed under vacuum and the residue aqueous phase was made alkaline with $\mathrm{NaOH}$ pellets. Then, the aqueous phase was extracted with AcOEt and the combined organic phases were dried $\left(\mathrm{Na}_{2} \mathrm{SO}_{4}\right)$. The solvent was evaporated under reduced pressure to give the desired amine (1a) as a yellow oil (4.5 g, 81\%). Spectroscopic data were in agreement with the literature [21].

4.1.1.2. Method B. In a microwave tube, ammonium acetate $(7.35 \mathrm{~g}$, $95.5 \mathrm{mmol})$ and sodium cyanoborohydride $(0.42 \mathrm{~g}, 6.7 \mathrm{mmol})$ were added to a solution of 1-(2,6-dimethylphenoxy)propan-2-one (3a) $(1.7 \mathrm{~g}, 9.55 \mathrm{mmol})$ in $15 \mathrm{~mL}$ of $\mathrm{MeOH}$. The reaction mixture was stirred for $11 \mathrm{~min}$ at $110^{\circ} \mathrm{C}$ in a microwave reactor at $95 \mathrm{~W}$ as power max. The processing of reaction mixture was carried out as reported for method A, obtaining 1a in $72 \%$ yield. Spectrometric and spectroscopic data were in agreement with the literature [21].

\subsubsection{1-(2,6-Dimethylphenoxy)propan-2-amine hydrochloride (1a.HCl)}

1a was treated with gaseous $\mathrm{HCl}$ to obtain the corresponding hydrochloride salt $(\mathbf{1} \mathbf{a} \cdot \mathbf{H C l})$ as a white solid which was recrystallized from $\mathrm{EtOH} / \mathrm{Et}_{2} \mathrm{O}$ to afford $2.9 \mathrm{~g} \mathrm{(40 \% )}$ of white crystals: $\mathrm{mp}$ 215-216 ${ }^{\circ} \mathrm{C} ;{ }^{1} \mathrm{H}$ NMR $\left.(500 \mathrm{MHz} \text {, DMSO-d })_{6}\right): \delta 1.35$ (d, $J=6.8 \mathrm{~Hz}, 2 \mathrm{H}$, $\left.\mathrm{CH}_{3} \mathrm{CH}\right), 2.23\left(\mathrm{~s}, 6 \mathrm{H}, \mathrm{CH}_{3} \mathrm{Ar}\right), 3.50-3.58(\mathrm{~m}, 1 \mathrm{H}, \mathrm{CH}), 3.82(\mathrm{~d}$, $\left.J=5.4 \mathrm{~Hz}, 2 \mathrm{H}, \mathrm{CH}_{2}\right), 6.91(\mathrm{t}, J=6.8 \mathrm{~Hz}, 1 \mathrm{H}, \mathrm{Ar}), 6.93(\mathrm{t}, J=7.3 \mathrm{~Hz}, 1 \mathrm{H}$, $\mathrm{Ar}), 7.00(\mathrm{~d}, J=7.8 \mathrm{~Hz}, 2 \mathrm{H}, \mathrm{Ar}), 8.50$ (br s, $\left.3 \mathrm{H}, \mathrm{NH}_{3}^{+}\right) ;{ }^{13} \mathrm{C}$ NMR (125 MHz, DMSO- $\left.d_{6}\right): \delta 15.5$ (2C), 16.4 (1C), 47.3 (1C), 72.2 (1C), 124.7 (1C), 128.9 (2C), 129.3 (2C), 130.9 (2); 154.8 (1C); Anal. $\left(\mathrm{C}_{11} \mathrm{H}_{18} \mathrm{NOCl}\right) \mathrm{C}, \mathrm{H}, \mathrm{N}$

\subsubsection{1-(2,6-Dimethylphenoxy)-3,3-dimethylbutan-2-amine (1b)}

Prepared as reported for $\mathbf{1 a}$ (Method B) starting from $\mathbf{3 b}$. The synthetic pathway provided $\mathbf{1 b}$ as a yellow oil in $34 \%$ yield. ${ }^{1} \mathrm{H}$ NMR (500 MHz, $\mathrm{CDCl}_{3}$ ): $\delta 0.97$ (s, 9H, $\left(\mathrm{CH}_{3}\right)_{3} \mathrm{C}$ ), 1.99 (br s, $2 \mathrm{H}, \mathrm{NH}_{2}$ ), 2.30 (s, 6H, $\mathrm{CH}_{3} \mathrm{Ar}$ ), 3.02 (dd, $\left.J=9.3,2.9 \mathrm{~Hz}, 1 \mathrm{H}, \mathrm{CHH}\right), 3.63(\mathrm{t}, J=9.3 \mathrm{~Hz}$,
$1 \mathrm{H}, \mathrm{CH}), 3.84(\mathrm{dd}, J=9.3,2.9 \mathrm{~Hz}, 1 \mathrm{H}, \mathrm{CHH}), 6.93(\mathrm{t}, J=7.3 \mathrm{~Hz}, 1 \mathrm{H}, \mathrm{Ar})$ 7.02 (d, $J=7.3 \mathrm{~Hz}, 2 \mathrm{H}, \mathrm{Ar}) ;{ }^{13} \mathrm{C}$ NMR $\left(125 \mathrm{MHz}, \mathrm{CDCl}_{3}\right): \delta 15.3(1 \mathrm{C})$, 16.4 (1C), 26.5 (3C), 33.0 (1C), 60.5 (1C), 65.9 (1C), 123.9 (1C), 128.9 (2C), 130.9 (2C), 155.8 (1C); GC-MS (70 eV) m/z (\%) $221\left(\mathrm{M}^{+}, 1\right), 86$ (100).

\subsubsection{1-(2,6-Dimethylphenoxy)-3,3-dimethylbutan-2-amine hydrochloride $(\mathbf{1 b} \cdot \mathbf{H C l})$}

Obtained as reported above for $1 \mathrm{a} \cdot \mathrm{HCl}$ : yield: $71 \%$; white crystals; mp: $215-216{ }^{\circ} \mathrm{C}$ (abs EtOH/Et $\left.{ }_{2} \mathrm{O}\right)$. Anal. $\left(\mathrm{C}_{14} \mathrm{H}_{24} \mathrm{NOCl}\right) \mathrm{C}, \mathrm{H}, \mathrm{N}$.

\subsubsection{2-(2,6-Dimethylphenoxy)-1-phenylethanamine (1c)}

Prepared as reported for 1a (Method B) starting from 3c. The synthetic pathway provided $1 \mathrm{c}$ as a yellow oil in $26 \%$ yield. ${ }^{1} \mathrm{H}$ NMR (500 MHz, $\mathrm{CDCl}_{3}$ ): $\delta 2.17\left(\mathrm{~s}, 6 \mathrm{H}, \mathrm{CH}_{3} \mathrm{Ar}\right.$ ), 3.88-4.08 (m, $2 \mathrm{H}, \mathrm{CH}_{2}$ ), 4.50-4.57 (m, 1H, CH), 6.88-7.03 (m, 3H, Ar), 7.13-7.22 (m, 3H, Ar), $7.24-7.38(\mathrm{~m}, 2 \mathrm{H}, \mathrm{Ar}), 7.50\left(\mathrm{~d}, J=6.8 \mathrm{~Hz}, 2 \mathrm{H}, \mathrm{CH}_{2}\right) ;{ }^{13} \mathrm{C}$ NMR (125 MHz, $\mathrm{CDCl}_{3}$ ): $\delta 15.3$ (1C), 16.3 (1C), 21.5 (1C), 65.9 (1C), 124.2 (1C), 125.3 (1C), 126.8 (1C), 127.4 (1C), 128.2 (1C), 128.6 (1C), 128.7 (1C), 128.9 (1C), 129.0 (2C), 130.8 (1C), 137.9 (1C); GC-MS (70 eV) m/ $z(\%) 241\left(\mathrm{M}^{+},<1\right), 106(100)$.

\subsubsection{2-(2,6-dimethylphenoxy)-1-phenylethanamine hydrochloride (1c. $\cdot \mathbf{H C l})$}

Obtained as reported above for $1 \mathrm{a} \cdot \mathrm{HCl}$ : yield: $80 \%$; white crystals; mp: $259-261{ }^{\circ} \mathrm{C}$ (abs EtOH/Et $\left.{ }_{2} \mathrm{O}\right)$; Anal. $\left(\mathrm{C}_{16} \mathrm{H}_{20} \mathrm{NOCl}\right) \mathrm{C}, \mathrm{H}, \mathrm{N}$.

\subsubsection{1-(2,6-Dimethylphenoxy)-3-methylbutan-2-amine hydrochloride (1d $\cdot \mathbf{H C l})$}

A solution of $\mathbf{5 d}(2.5 \mathrm{~g}, 8.1 \mathrm{mmol})$ in anhydrous $\mathrm{Et}_{2} \mathrm{O}(15 \mathrm{~mL})$ was saturated with gaseous $\mathrm{HCl}$ and stirred at room temperature for $15 \mathrm{~min}$. Removal of the solvent under reduced pressure gave a solid $(1.5 \mathrm{~g}, 75 \%)$ which was recrystallized from $\mathrm{EtOH} / \mathrm{Et}_{2} \mathrm{O}$ : white crystals: mp $171-172{ }^{\circ} \mathrm{C}\left(\right.$ abs EtOH/Et $\left.{ }_{2} \mathrm{O}\right)$; Anal. $\left(\mathrm{C}_{13} \mathrm{H}_{22} \mathrm{NOCl} 0.17 \mathrm{H}_{2} \mathrm{O}\right)$ $\mathrm{C}, \mathrm{H}, \mathrm{N}$.

\subsubsection{1-(2,6-Dimethylphenoxy)-3-methylbutan-2-amine (1d)}

Obtained as a yellow oil by extraction from the corresponding hydrochloride salt. ${ }^{1} \mathrm{H}$ NMR (500 MHz, $\left.\mathrm{CDCl}_{3}\right): \delta 0.98(\mathrm{~d}, J=7.3 \mathrm{~Hz}$, $\left.3 \mathrm{H}, \mathrm{CH}_{3} \mathrm{CHCH}_{3}\right), 0.99$ (d, $\left.J=6.8 \mathrm{~Hz}, 3 \mathrm{H}, \mathrm{CH}_{3} \mathrm{CHCH}_{3}\right), 1.73-1.82(\mathrm{~m}$ $1 \mathrm{H}, \mathrm{CHCH}_{3}$ ), 1.88 (br s, $2 \mathrm{H}, \mathrm{NH}_{2}$ ), 2.30 (s, 6H, $\mathrm{CH}_{3} \mathrm{Ar}$ ), 2.98-3.08 (m, $\left.1 \mathrm{H}, \mathrm{CHCH}_{2}\right), 3.64\left(\mathrm{t}, J=8.8 \mathrm{~Hz}, 1 \mathrm{H}, \mathrm{CHHCH}_{2}\right), 3.77(\mathrm{dd}, J=3.8,8.8 \mathrm{~Hz}$, $\left.1 \mathrm{H}, \mathrm{CHHCH}_{2}\right), 6.92(\mathrm{t}, J=7.8 \mathrm{~Hz}, 1 \mathrm{H}, \mathrm{Ar}), 7.01(\mathrm{~d}, J=7.8 \mathrm{~Hz}, 2 \mathrm{H}, \mathrm{Ar})$; ${ }^{13} \mathrm{C}\left(125 \mathrm{MHz}, \mathrm{CDCl}_{3}\right): \delta 15.3(1 \mathrm{C}), 16.4$ (1C), $18.2(1 \mathrm{C}), 19.4$ (1C), 30.8 (1C), 57.1 (1C), 65.9 (1C), 123.8 (1C), 128.9 (2C). 129.0 (1C), 130.1 (1C), 155.7 (1C); MS (70 eV) m/z (\%) $207\left(\mathrm{M}^{+}, 3\right), 72(100)$.

\subsubsection{1-(2,6-Dimethylphenoxy)-3-phenylpropan-2-amine} hydrochloride $(\mathbf{1} \cdot \mathbf{H C l})$

Prepared as reported for $\mathbf{1 d} \cdot \mathbf{H C l}$ starting from $\mathbf{5 e}$. The synthetic pathway provided $\mathbf{1 e} \cdot \mathbf{H C l}$ as a white solid in $92 \%$ yield. The solid was recrystallized from abs $\mathrm{EtOH} / \mathrm{Et}_{2} \mathrm{O}$ to give white crystals (40\%); mp: $218-219{ }^{\circ} \mathrm{C} .{ }^{1} \mathrm{H}$ NMR (300 MHz, $\left.\mathrm{CD}_{3} \mathrm{OD}\right): \delta 2.21$ (s, 6H, $\mathrm{CH}_{3} \mathrm{Ar}$ ), 3.02-3.24 (m, 2H, $\left.\mathrm{CH}_{2} \mathrm{Ar}\right), 3.72-4.0\left(\mathrm{~m}, 3 \mathrm{H}, \mathrm{CH}_{2} \mathrm{CH}\right), 6.95-7.05(\mathrm{~m}$, $3 \mathrm{H}, \mathrm{Ar}), 7.25-7.45(\mathrm{~m}, 5 \mathrm{H}, \mathrm{Ar}) ;{ }^{13} \mathrm{C}$ NMR (100 MHz, CD $\mathrm{CD}_{3} \mathrm{OD} \delta 15.3$ (2C), $35.4(1 \mathrm{C}), 53.5(1 \mathrm{C}), 70.0$ (1C), $124.6(1 \mathrm{C}), 127.4(1 \mathrm{C}), 129.0(4 \mathrm{C})$, 129.1 (2C), 130.5 (2C). 135.5 (1C), 154.6 (1C). Anal. $\left(\mathrm{C}_{17} \mathrm{H}_{22} \mathrm{NOCl}\right) \mathrm{C}$, $\mathrm{H}, \mathrm{N}$.

\subsection{Pharmacology}

\subsubsection{Details for functional studies}

4.2.1.1. Guinea-pig atrial preparations. Female guinea pigs (300-400 g) were sacrificed by cervical dislocation. After thoracotomy, the heart was immediately removed and washed by 
perfusion through the aorta with oxygenated Tyrode solution of the following composition $(\mathrm{mM})$ : $136.9 \mathrm{NaCl}, 5.4 \mathrm{KCl}, 2.5 \mathrm{CaCl}_{2}, 1.0$ $\mathrm{MgCl}_{2}, 0.4 \mathrm{NaH}_{2} \mathrm{PO}_{4} \times \mathrm{XH}_{2} \mathrm{O}, 11.9 \mathrm{NaHCO}_{3}$ and 5.5 glucose. The physiological salt solution (PSS) was buffered at $\mathrm{pH} 7.4$ by saturation with $95 \% \mathrm{O}_{2}-5 \% \mathrm{CO}_{2}$ gas, and the temperature was maintained at $35{ }^{\circ} \mathrm{C}$. Isolated guinea pig heart preparations were used, spontaneously beating right atria and left atria driven at $1 \mathrm{~Hz}$. For each preparation, the entire left and right atria were dissected from the ventricles, cleaned of excess tissue, and hung vertically in a $15 \mathrm{~mL}$ organ bath containing the PSS continuously bubbled with $95 \%$ $\mathrm{O}_{2}-5 \% \mathrm{CO}_{2}$ gas at $35{ }^{\circ} \mathrm{C}, \mathrm{pH}$ 7.4. The contractile activity was recorded isometrically by means of a force transducer (FT 0.3, Grass Instruments Corporation, Quincy, MA, USA) using Power Lab ${ }^{\circledR}$ software (AD-Instruments Pty Ltd, Castle Hill, Australia). The left atria were stimulated by rectangular pulses of $0.6-0.8 \mathrm{~ms}$ duration and about 50\% threshold voltage through two platinum contact electrodes in the lower holding clamp (Grass S88 Stimulator). The right atrium was in spontaneous activity. After the tissue was beating for several minutes, a length-tension curve was determined, and the muscle length was maintained which elicited $90 \%$ of maximum contractile force observed at the optimal length. A stabilization period of 45-60 min was allowed before the atria were used to test compounds. During the equilibration period, the bathing solution was changed every $15 \mathrm{~min}$ and the threshold voltage was ascertained for the left atria. Atrial muscle preparations were used to examine the inotropic and chronotropic activity of the compounds $(0.01,0.05,0.1,0.5,1,5,10,50$, and $100 \mu \mathrm{M})$ dissolved in PSS. During the construction of cumulative dose-response curves, the next higher concentration of the compounds was added only after the preparation reached a steady state.

4.2.1.2. Alternating current induced arrhythmia in Guinea pig left atrial preparations $[32,33]$. Left atria from guinea pigs were fixed to platinum wire electrodes and placed between two parallel platinum field electrodes. The preparations were mounted vertically in a $15 \mathrm{~mL}$ organ bath containing a modified Krebs-Henselait solution of the following composition (mM): $118 \mathrm{NaCl}, 4.7 \mathrm{KCl}, 2.5 \mathrm{CaCl}_{2}, 1.2$ $\mathrm{MgSO}_{4}, 1.2 \mathrm{NaH}_{2} \mathrm{PO}_{4} \mathrm{xH} \mathrm{H}_{2} \mathrm{O}, 24.9 \mathrm{NaHCO}_{3}$, and 10.1 glucose. The solution was buffered at $\mathrm{pH} 7.4$ by saturation with $95 \% \mathrm{O}_{2}-5 \% \mathrm{CO}_{2}$ gas, and the temperature was maintained at $35^{\circ} \mathrm{C}$. The preparations were connected to a force transducer. Isometric force contraction was recorded using Power Lab ${ }^{\circledR}$ software. Arrhythmias were induced by application of sinusoidal alternating current $(50 \mathrm{~Hz})$ of increasing strength to the isolated heart preparations, 2 and $4 \mathrm{~mA} /$ $\left(\mathrm{cm}^{2} \mathrm{~s}\right)$ to induce arrhythmia corresponding to an increase in field intensity of $0.3 \mathrm{~V} /(\mathrm{cm} \mathrm{s})$. The current intensity $\left(\mathrm{mA} / \mathrm{cm}^{2}\right)$ at which extra beats occurred was called "threshold of ac-arrhythmia" [34]. The preparations were allowed to stabilize for $60 \mathrm{~min}$. Then concentration-response curves for threshold of ac-arrhythmia were recorded by cumulative application of compounds to the bathing solution every $30 \mathrm{~min}$.

4.2.1.3. Guinea-Pig aortic strips. The thoracic aorta was removed and placed in Tyrode solution of the following composition ( $\mathrm{mM}$ ): $118 \mathrm{NaCl}, 4.75 \mathrm{KCl}, 2.54 \mathrm{CaCl}_{2}, 1.20 \mathrm{MgSO}_{4}, 1.19 \mathrm{KH}_{2} \mathrm{PO}_{4}, 25 \mathrm{NaHCO}_{3}$ and 11 glucose equilibrated with $95 \% \mathrm{O}_{2}-5 \% \mathrm{CO}_{2}$ gas at $\mathrm{pH}$ 7.4. The vessel was cleaned of extraneous connective tissue. Two helicoidal strips ( $10 \mathrm{~mm} \times 1 \mathrm{~mm}$ ) were cut from each aorta beginning from the end most proximal to the heart. Vascular strips were then tied with surgical thread (6-0) and suspended in a jacketed tissue bath $(15 \mathrm{~mL})$ containing aerated PSS at $35{ }^{\circ} \mathrm{C}$. Aortic strips were subjected to a resting force of $1 \mathrm{~g}$. Strips were secured at one end to a force displacement transducer (FT 0.3, Grass Instruments Corporation) to monitor changes in isometric contraction and washed every 20 min with fresh PSS for $1 \mathrm{~h}$ after the equilibration period; guinea pig aortic strips were contracted by washing in PSS containing $80 \mathrm{mM} \mathrm{KCl}$ (equimolar substitution of $\mathrm{K}^{+}$for $\mathrm{Na}^{+}$). After the contraction reached a plateau (about $45 \mathrm{~min}$ ) the compounds ( 0.1 , $0.5,1,5,10,50$, and $100 \mu \mathrm{M}$ ) were added cumulatively to the bath allowing for any relaxation to obtain an equilibrated level of force. Addition of the drug vehicle had no appreciable effect on $\mathrm{K}^{+}$induced contraction (PSS for all compounds).

4.2.1.4. Statistical analysis. Data were analyzed using Student's $t$ test and are presented as mean \pm S.E.M. Since the drugs were added in cumulative manner, the difference between the control and the experimental values at each concentration were tested for a $P$ value $<0.05$. The potency of drugs defined as $\mathrm{EC}_{50}$ and $\mathrm{IC}_{50}$ was evaluated from log concentration-response curves (Probit analysis using Litchfield and Wilcoxon) [35] in the appropriate pharmacological preparations.

\subsubsection{Details for motor coordination studies}

4.2.2.1. Rota-rod test. The apparatus consisted of a base platform and a rotating rod of $3 \mathrm{~cm}$ diameter with a non-slippery surface. The rod was placed at a height of $15 \mathrm{~cm}$ from the base. The rod, $30 \mathrm{~cm}$ in length, was divided into five equal sections by six disks. Thus, up to five mice were tested simultaneously on the apparatus, with a rod-rotating speed of $16 \mathrm{rpm}$. The integrity of motor coordination was assessed on the basis of the number of falls from the rod in $30 \mathrm{~s}$ according to Vaught et al. [36].

\subsubsection{Details for cytotoxicity studies}

4.2.3.1. Cell cultures. HepG2 (Sigma-Aldrich, St. Louis, MO) cells were cultured in DMEM-Dulbecco's modified Eagle's medium (Sigma-Aldrich, St. Louis, MO) supplemented with $10 \%$ (v/v) inactivated fetal bovine serum (PAA Laboratories GmbH, Austria), $2 \mathrm{mM}$ L-glutamine (Sigma-Aldrich, St. Louis, MO), $100 \mu \mathrm{g} / \mathrm{mL}$ penicillin and $100 \mu \mathrm{g} / \mathrm{mL}$ streptomycin (Sigma-Aldrich, St. Louis, MO) at $37^{\circ} \mathrm{C}$ in $5 \% \mathrm{CO}_{2}$. For experiments, the cells were grown to $70 \%$ confluence and then were treated with test compounds in serum free media for the indicated times.

4.2.3.2. Cell viability assay. HepG2 cell viability was assessed using a conventional MTT reduction assay [37]. This method is based on the ability of viable cells to metabolize MTT, a water-soluble salt (yellow color), by cellular oxidoreductase into a water-insoluble blue formazan product. Therefore, the amount of formazan produced is proportional to the viable cells. Briefly, viable cells $\left(10^{4} /\right.$ well) were plated into sterile 96-Well Cell Culture Cluster (Corning, NY 14831) and incubated with different concentrations $(0.05-2 \mathrm{mM})$ of tested compounds for $2 \mathrm{~h}$ at $37{ }^{\circ} \mathrm{C}$ in $5 \% \mathrm{CO}_{2}$. At the end of incubation, the culture medium was replaced by a solution of MTT $0.5 \mathrm{mg} / \mathrm{mL}$ (Sigma-Aldrich, Milan, Italy) in PBS (Sigma-Aldrich, Milan, Italy). After $2 \mathrm{~h}$ incubation at $37{ }^{\circ} \mathrm{C}$ in $5 \% \mathrm{CO}_{2}$ this solution was removed and $200 \mu \mathrm{l}$ of DMSO was added to each well to dissolve the formazan product. Absorbance values at $570 \mathrm{~nm}$ were measured using a plate reader Victor $\mathrm{V}^{3}$ (Perkin-Elmer) and DMSO medium was used as blank solution. Results are expressed as the percentage of MTT reduction respect to control cells. All experiments were carried out in sextuplicate and were repeated twice.

\subsubsection{Details for P-gp interaction studies}

4.2.4.1. Cell cultures. MDCK-MDR1 cells are a gift of Prof. P. Borst, NKI-AVL Institute, Amsterdam, Netherland. MDCK cells were grown in DMEM high glucose supplemented with $10 \%$ fetal bovine serum, $2 \mathrm{mM}$ glutamine, $100 \mathrm{U} / \mathrm{mL}$ penicillin, $100 \mu \mathrm{g} / \mathrm{mL}$ streptomycin, in a humidified incubator at $37{ }^{\circ} \mathrm{C}$ with a $5 \% \mathrm{CO}_{2}$ atmosphere.

4.2.4.2. Calcein-AM experiment. These experiments were carried 
out as described by Feng et al. with minor modifications [38]. Each cell line $(50,000$ cells per well) was seeded into black CulturePlate 96/wells plate with $100 \mu \mathrm{l}$ medium and allowed to become confluent overnight. $100 \mu \mathrm{l}$ of test compounds were solubilized in culture medium and added to monolayers. 96/Wells plate was incubated at $37{ }^{\circ} \mathrm{C}$ for $30 \mathrm{~min}$. Calcein-AM was added in $100 \mu \mathrm{l}$ of Phosphate Buffered Saline (PBS) to yield a final concentration of $2.5 \mu \mathrm{M}$ and plate was incubated for $30 \mathrm{~min}$. Each well was washed 3 times with ice cold PBS. Saline buffer was added to each well and the plate was read to Victor3 (PerkinElmer) at excitation and emission wavelengths of $485 \mathrm{~nm}$ and $535 \mathrm{~nm}$, respectively. In these experimental conditions Calcein cell accumulation in the absence and in the presence of tested compounds was evaluated and fluorescence basal level was estimated by untreated cells. In treated wells the increase of fluorescence with respect to basal level was measured. $\mathrm{EC}_{50}$ values were determined by fitting the fluorescence increase percentage versus log [dose].

\section{Acknowledgment}

This work was accomplished thanks to the financial support of the Italian Ministero dell'Istruzione, dell'Università e della Ricerca Grant MIUR 2005033023-001 to C.F.

\section{Appendix A. Supplementary data}

Supplementary data related to this article can be found at http:// dx.doi.org/10.1016/j.ejmech.2016.05.046.

\section{References}

[1] S. Nattel, G. Duker, L. Carlsson, Model systems for the discovery and development of antiarrhythmic drug, Prog. Biophys. Mol. Biol. 98 (2008) 328-339.

[2] J.C. Lopshire, D.P. Zipe, Sudden cardiac death: better understanding of risks, mechanisms, and treatment, Circulation 114 (2006) 1134-1136.

[3] M. Muraglia, M. De Bellis, A. Catalano, A. Carocci, C. Franchini, A. Carrieri, C. Fortugno, C. Bertucci, J.F. Desaphy, A. De Luca, D. Conte Camerino, F. Corbo, $\mathrm{N}$-aryl-2,6-dimethylbenzamides, a new generation of tocainide analogues as blockers of skeletal muscle voltage-gated sodium channels, J. Med. Chem. 57 (2014) 2589-2600.

[4] A. Carocci, A. Catalano, C. Bruno, G. Lentini, C. Franchini, M. De Bellis, A. De Luca, D. Conte Camerino, Synthesis and in vitro sodium channel blocking activity evaluation of novel homochiral mexiletine analogs, Chirality 22 (2010) 299-307.

[5] D. Conte Camerino, D. Tricarico, J.-F. Desaphy, Ion channel pharmacology, Neurotherapeutics 4 (2007) 184-198.

[6] A. Catalano, A. Carocci, M.S. Sinicropi, Mexiletine metabolites: a review, Curr. Med. Chem. 22 (2015) 1400-1413.

[7] A. Catalano, A. Carocci, G. Fracchiolla, C. Franchini, G. Lentini, V. Tortorella, A. De Luca, M. De Bellis, J.-F. Desaphy, D. Conte Camerino, Stereospecific synthesis of "para-hydroxymexiletine" and sodium channel blocking activity evaluation, Chirality 16 (2004) 72-78.

[8] S.J. Snedecor, L. Sudharshan, J.C. Cappelleri, A. Sadosky, S. Mehta, M. Botteman, Systematic review and meta-analysis of pharmacological therapies for painful diabetic peripheral neuropathy, Pain Pract. 14 (2014) 167-184.

[9] S. Isose, S. Misawa, K. Sakurai, K. Kanai, K. Shibuya, Y. Sekiguchi, S. Nasu, Y. Noto, Y. Fujimaki, K. Yokote, S. Kuwabara, Mexiletine suppresses nodal persistent sodium currents in sensory axons of patients with neuropathic pain, Clin. Neurophysiol. 121 (2010) 719-724.

[10] J.-F. Desaphy, R. Carbonara, T. Costanza, D. Conte Camerino, Preclinical evaluation of marketed sodium channel blockers in a rat model of myotonia discloses promising antimyotonic drugs, Exp. Neurol. 255 (2015) 96-102.

[11] Y. Gao, X. Xue, D. Hu, W. Liu, Y. Yuan, H. Sun, L. Li, K.W. Timothy, L. Zhang, C. Li, G.-X. Yan, Inhibition of late sodium current by mexiletine: a novel pharmotherapeutical approach in Timothy syndrome, Circ. Arrhyth. Electrophysiol. 6 (2013) 614-622.

[12] M. Weiss, Z. Simmons, N. Atassi, M. Graves, N. Parziale, J. Salameh, C. Quinn, R. Brown, B. Distad, J. Trivedi, J. Shefner, A. Duleep, R. Barohn, M. Dimachkie, A. McVey, A. Pestronk, A. Swenson, E. Macklin, A. Knox, K. Gilardi, M. Cudkowicz, A phase 2 study of mexiletine in sporadic amyotrophic lateral sclerosis (S50.004), Neurology 84 (14 suppl) (2005). S50.004.

[13] M. Bucchia, A. Ramirez, V. Parente, C. Simone, M. Nizzardo, F. Magri, S. Dametti, S. Corti, Therapeutic development in amyotrophic lateral sclerosis, Clin. Ther. 37 (2015) 668-680.

[14] K. Shibuya, S. Misawa, H. Kimura, Y.I. Noto, et al., A single blind randomized controlled clinical trial of mexiletine in amyotrophic lateral sclerosis: efficacy and safety of sodium channel blocker phase II trial, Amyotroph. Lateral Scler. Front. Degener. 16 (2015) 353-358.

[15] A. Catalano, J.-F. Desaphy, G. Lentini, A. Carocci, A. Di Mola, C. Bruno R. Carbonara, A. De Palma, R. Budriesi, C. Ghelardini, M.G. Perrone, N.A. Colabufo, D. Conte Camerino, C. Franchini, Synthesis and toxicopharmacological evaluation of $m$-hydroxymexiletine, the first metabolite of mexiletine more potent than the parent compound on voltage-gated sodium channels, J. Med. Chem. 55 (2012) 1418-1422.

[16] E. Matthews, M.G. Hanna, Repurposing of sodium channel antagonists as potential new anti-myotonic drugs, Exp. Neurol. 261 (2014) 812-815.

[17] C. Franchini, A. Carocci, A. Catalano, M.M. Cavalluzzi, F. Corbo, G. Lentini, A. Scilimati, P. Tortorella, D. Conte Camerino, A. De Luca, Optically active mexiletine analogues as stereoselective blockers of voltage-gated $\mathrm{Na}^{+}$channels, J. Med. Chem. 46 (2003) 5238-5248.

[18] J.-F. Desaphy, A. Dipalma, T. Costanza, R. Carbonara, M.M. Di Nardo, A. Catalano, A. Carocci, G. Lentini, C. Franchini, D. Conte Camerino, Molecular insights into the local anesthetic receptor within voltage-gated sodium channels using hydroxylated analogs of mexiletine, Front. Pharmacol. 3 (2012) 1-12.

[19] A. De Luca, S. Talon, M. De Bellis, J.-F. Desaphy, C. Franchini, G. Lentini A. Catalano, F. Corbo, V. Tortorella, D. Conte Camerino, Inhibition of skeletal muscle sodium currents by mexiletine analogues: specific hydrophobic interactions rather than lipophilia per se account for drug therapeutic profile, Naunyn Schmiedeb. Arch. Pharmacol. 367 (2003) 318-327.

[20] M. De Bellis, A. De Luca, J.-F. Desaphy, R. Carbonara, J.A. Heiny, A. Kennedy, A. Carocci, M.M. Cavalluzzi, G. Lentini, C. Franchini, D. Conte Camerino, Combined modifications of mexiletine pharmacophores for new lead blockers of Nav1.4 channels, Biophys. J. 104 (2013) 344-354.

21] A. Carocci, A. Catalano, F. Corbo, A. Duranti, R. Amoroso, C. Franchini, G. Lentini, V. Tortorella, Stereospecific synthesis of mexiletine and related compounds: Mitsunobu versus Williamson reaction, Tetrahedron Asymmetry 11 (2000) 3619-3634.

[22] M.M. Cavalluzzi, M. Viale, C. Bruno, A. Carocci, A Catalano, A Carrieri, C. Franchini, G. Lentini, A convenient synthesis of lubeluzole and its enantiomer: evaluation as chemosensitizing agents on human ovarian adenocarcinoma and lung carcinoma cells, Bioorg. Med. Chem. Lett. 23 (2013) $4820-4823$.

[23] A. Carocci, G. Lentini, A. Catalano, M.M. Cavalluzzi, C. Bruno, M. Muraglia, N.A. Colabufo, N. Galeotti, F. Corbo, R. Matucci, C. Ghelardini, C. Franchini, Chiral aryloxyalkylamines: selective 5- $\mathrm{HT}_{1 \mathrm{~B} / \mathrm{D}}$ activation and analgesic activity, ChemMedChem 5 (2010) 696-704.

[24] A. Catalano, A. Carocci, M.M. Cavalluzzi, A. Di Mola, G. Lentini, A. Lovece A. Dipalma, T. Costanza, J.-F. Desaphy, D. Conte Camerino, C. Franchini, Hydroxylated analogs of mexiletine as tools for structural-requirements investigation of the sodium channel blocking activity, Arch. Pharm. Chem. Life. Sci. 343 (2010) 325-332.

[25] C. Bruno, A. Carocci, A. Catalano, M.M. Cavalluzzi, F. Corbo, C. Franchini, G. Lentini, V. Tortorella, Facile, alternative route to lubeluzole, its enantiomer, and the racemate, Chirality 18 (2006) 227-231.

[26] A. Catalano, R. Budriesi, C. Bruno, A. Di Mola, I. Defrenza, M.M. Cavalluzzi, M. Micucci, A. Carocci, C. Franchini, G. Lentini, Searching for new antiarrhythmic agents: evaluation of meta-hydroxymexiletine enantiomers, Eur. J Med. Chem. 65 (2013) 511-516.

[27] M. De Bellis, A. De Luca, F. Rana, M.M. Cavalluzzi, A. Catalano, G. Lentini, C. Franchini, V. Tortorella, D. Conte Camerino, Evaluation of the pharmacological activity of the major mexiletine metabolites on skeletal muscle sodium currents, Br. J. Pharmacol. 149 (2006) 300-310.

[28] A. Carocci, A. Catalano, C. Bruno, A. Lovece, M. Roselli, M.M. Cavalluzzi, F. De Santis, A. De Palma, M.R. Rusciano, M. Illario, C. Franchini, G. Lentini, N(Phenoxyalkyl)amides as $\mathrm{MT}_{1}$ and $\mathrm{MT}_{2}$ ligands: antioxidant properties and inhibition of $\mathrm{Ca}^{2+} / \mathrm{CaM}-d e p e n d e n t$ kinase II, Bioorg. Med. Chem. 21 (2013) 847-851.

[29] A. Carocci, A. Catalano, F. Turi, A. Lovece, M.M. Cavalluzzi, C. Bruno, N.A. Colabufo, M. Contino, M.G. Perrone, C. Franchini, G. Lentini, Stereosective modulation of P-glycoprotein by chiral small molecules, ChemMedChem 11 (2016) 93-101.

[30] W.C. Still, M. Kahn, A. Mitra, Rapid chromatographic technique for preparative separation with moderate resolution, J. Org. Chem. 43 (1978) 2923-2925.

[31] R. Gualdani, F. Tadini-Buoninsegna, M.G. Roselli, I. Defrenza, M. Contino, N.A. Colabufo, G. Lentini, Inhibition of hERG potassium channel by the antiarrhythmic agent mexiletine and its metabolite $m$-hydroxymexiletine, Pharmacol. Res. Perspect. (3) (2015) e00160, http://dx.doi.org/10.1002/prp2.160.

[32] U. Borchard, R. Bösken, K. Greeff, Characterization of antiarrhythmic drugs by alternating current induced arrhythmias in isolated heart tissues, Arch. Int Pharmacodyn. 256 (1982) 253-268.

[33] U. Borchard, S. Clemm, C. Hirth, Influence of antiarrhythmogenic and antiarrhythmic agents on alternating current-induced arrhythmias in Guinea-pig heart preparations, Arch. Int. Pharmacodyn. 269 (1984) 83-93.

[34] U. Borchard, Untersuchungen zum Wirkungsmechanismus und zur pharmakologischen Charakterisierung von Lokalanästhetika, Habilit. Düsseld. (1978).

[35] R.J. Tallarida, R.B. Murray, Manual of Pharmacologic Calculations with Computer Programs, second ed., Springer-Verlag, New York, 1987.

[36] J. Vaught, K. Pelley, L.G. Costa, P. Setter, S.J. Enna, A comparison of the antinociceptive responses to GABA - receptor agonists THIP and baclofen, 
Neuropharmacology 24 (1985) 211-216.

[37] M.V. Berridge, A.S. Tan, Characterization of the cellular reduction of 3-(4,5dimethylthiazol-2-yl)-2,5-diphenyltetrazolium bromide (MTT): subcellula localization, substrate dependence, and involvement of mitochondrial electron transport in MTT reduction, Arch. Biochem. Biophys. 303 (1993) 474-482.

[38] B.J. Feng, B. Mills, R.E. Davidson, R.J. Mireles, J.S. Janiszewski, M.D. Troutman, S.M. de Morais, Drug Metab. Dispos. 36 (2008) 268-275. 